\title{
Effect of Date of Sowing and Varieties on Yield of Kharif Bt-cotton in Middle Gujarat Agro-Climatic Region
}

\author{
Vibha Tak*, Vyas Pandey and P. K. Parmar
}

Department of Agricultural Meteorology, B. A. College of Agriculture, Anand Agricultural University, Anand, India

*Corresponding author

\section{Keywords}

Bt-cotton, Sowing dates, Variety, growth, Yield attributes etc

\section{Article Info}

Accepted:

12 December 2020

Available Online: 10 January 2021
A field experiment was conducted at B. A. College of Agriculture, A.A.U., Anand to analyze the yield attributes of Bt- cotton. The experiment was carried out in a split plot design with three dates of sowing and two Btcotton cultivars. The results of field experiment revealed that the difference in cotton seed yield and biomass as well as plant height and no. of bolls/plant were found significant due to date of sowing. Yield and yield attributes character were found o decrease with delay sowing. There was no difference found in yield and yield attributes characters due to varieties.

\section{Introduction}

Cotton is an important fibre yielding crop of global importance, which is grown in tropical and subtropical regions of more than 80 countries world over. India is the only country, where all four cultivated species of cotton are grown on commercial scale and has one of the largest growing area of cotton in the world. India remains the leading country in terms of area under cotton cultivation and raw cotton production in the world. As per $\mathrm{CAB}$ estimate, cotton production in India during 2017-18 is expected to produce 377 lakh bales of $170 \mathrm{~kg}$ from 122 lakh hectares with a productivity of $524 \mathrm{~kg}$ lint/ha. During the current year 2017-18, Gujarat, Maharashtra and Telangana were the major cotton growing states covering around $71 \%$ (86.4 lakh hectare) in area under cotton cultivation and $65 \%$ (246 lakh bales) of cotton production in India (Anon, 2018). n. The cotton production in Gujarat increased from 95 to 104 lakh bales compared to last year but reduction in cotton production estimated in Maharashtra and Madhya Pradesh to the tune of $3.95 \%$ and $2.44 \%$, respectively (Anon, 2018). India maintaining the position of leading cotton producer in the world, China and United States has increased cotton 
production around $23 \%$ as compared to last year. It was just $5.56 \%$ increase in cotton production this year, though larger area brought under cotton cultivation in India. It is also estimated that the area under cotton increased from 292.23 to 333.85 lakh hectare this year at an increase of $14.24 \%$. In India, the area under cotton increased from 105 to 123 lakh hectares with an increase of $17 \%$ this year, also significant increase in area under cotton in China, the United States to the tune of 20\% from last year (Anon, 2018). Cotton seed cake, after extraction of oil is good organic manure and contains about $6 \%$ nitrogen, 3\% phosphorus and $2 \%$ potash. Cotton seed, cotton linters and pulp obtained during oil extraction and cotton meal are good concentrated feed for cattles. Out of about 50 species of cotton plants in the world, only four have been domestically cultivated for cotton fibres. Gossypium hirsutum and Gossypium barbadense are the most commonly cultivated species of cotton in the world. Gossypium hirsutum variety is the most important agricultural cotton, accounting for more than $90 \%$ of world fibre production (Anon, 2013).

Cotton is cultivated in India from subHimalayan region of Punjab in the north to Kerala in south and from dry regions of Kutch to high rainfall areas of Manipur in east. Cultivation of hybrids, Bt cotton varieties, latest production technology and plant protection technologies, adoption of scientific and agronomic practices by farmers, increase in area under irrigation, Government policies on $R \& D$ and price support, are all responsible for the present drastic changes of Indian cotton scenario to its present position. The technology was found to be very favorable for farmers all over the world and has been responsible for tremendous reduction in the overall use of insecticides against cotton bollworms. Insect resistance, however, can reduce the effectiveness of $B t$ crops and is therefore a major concern for the long-term sustainability of $B t$ crops.

\section{Materials and Methods}

A study was conducted during the kharif season 2012 at the Agronomy farm of B. A. College of Agriculture, India situated at $22^{\circ}$ $35^{\prime} \mathrm{N}$ latitude and $72^{\circ} 55^{\prime} \mathrm{E}$ longitude and at an altitude of $45.1 \mathrm{~m}$ above mean sea level. Experiment carried out in a split plot design with two Bt-cotton cultivars viz. Vikram-5 $\left(\mathrm{V}_{1}\right)$ and $\mathrm{RCH}-2\left(\mathrm{~V}_{2}\right)$ as a main plot treatment and three dates of sowing 25th May $\left(\mathrm{D}_{1}\right), 10$ th June $\left(\mathrm{D}_{2}\right)$ and 25th June $\left(\mathrm{D}_{3}\right)$ as sub-plot treatment with four replications. Three dates of sowing provided three different environments in terms of thermal and moisture regimes. The location of the field experiment at the research farm falls under middle Gujarat Agro-climatic Zone-III of the Gujarat State and is $90 \mathrm{~km}$ away from the Arabian Sea. Its climate has been classified as semi-arid tropical. The average annual rainfall of study area is $839.6 \mathrm{~mm}$ and is received through Southwest monsoon wind currents during the 3rd week of June and withdraws by the 2nd week of September. The weather remains dry from October to May. Summer is hot and sometimes mercury crosses $45.0^{\circ} \mathrm{C}$ in the month of May, while winter is cool and dry and temperature drops up to $5.0^{\circ} \mathrm{C}$ during January. The soil of the experimental site is representative of the soils of the region and is popularly known as "Goradu" soil. This soil is of alluvial origin and classified as "Loamy sand" and belongs to Entisols. The experimental field had a good drainage as well as fair moisture retentive capacity.

\section{Results and Discussion}

\section{Plant height}

Data regarding plant height of Bt-cotton recorded at harvest as influenced by variety 
and dates of sowing are presented in Table 1. The higher plant height cultivar $\mathrm{RCH}-2$ recorded $(101 \mathrm{~cm} /$ plant $)$ than that of Vikram$5(99 \mathrm{~cm} /$ plant $)$ at harvest time. As obtained in periodical observations, the plant height observed where the lowest plant height at harvest time was also similar. Cotton sown on May 25th $\left(D_{1}\right)$ produce maximum height 106 $\mathrm{cm}$ followed by $\mathrm{D}_{2}(101 \mathrm{~cm})$ and $\mathrm{D}_{3}(91 \mathrm{~cm})$. The results were in accordance to Awan et al., (2011) for Bt-cotton yield.

Table.1 Plant height $(\mathrm{cm})$ influenced by different date of sowing and variety

\begin{tabular}{|l|c|c|c|c|}
\hline \multirow{2}{*}{ Treatments } & \multicolumn{4}{|c|}{ Plant height $(\mathbf{c m})$} \\
\cline { 2 - 5 } & $\mathrm{D}_{1}$ & $\mathrm{D}_{2}$ & $\mathrm{D}_{3}$ & Mean \\
\hline $\mathbf{V}_{\mathbf{1}}$ (Vikram-5) & 103 & 99 & 93 & $\mathbf{9 9}$ \\
\hline V $_{\mathbf{2}}$ (RCH-2) & 110 & 103 & 89 & $\mathbf{1 0 1}$ \\
\hline Mean & $\mathbf{1 0 6}$ & $\mathbf{1 0 1}$ & $\mathbf{9 1}$ & \\
\hline
\end{tabular}

Table.2 Number of bolls/plant influenced by different date of sowing and variety

\begin{tabular}{|l|l|l|l|l|}
\hline \multirow{2}{*}{ Treatment } & \multicolumn{2}{|c|}{} & \multicolumn{3}{c|}{ No. of bolls/plant } \\
\cline { 2 - 5 } & $\mathrm{D}_{1}$ & $\mathrm{D}_{2}$ & $\mathrm{D}_{3}$ & Mean \\
\hline $\mathbf{V}_{\mathbf{1}}$ & 33 & 27 & 26 & $\mathbf{2 9}$ \\
\hline $\mathbf{V}_{\mathbf{2}}$ & 39 & 31 & 29 & $\mathbf{3 3}$ \\
\hline Mean & $\mathbf{3 6}$ & $\mathbf{2 9}$ & $\mathbf{2 8}$ & \\
\hline
\end{tabular}

Table.3 Seed cotton yield and Biomass yield influenced by different date of sowing and Variety

\begin{tabular}{|c|c|c|}
\hline Treatments & $\begin{array}{l}\text { Seed cotton yield } \\
(\mathrm{kg} / \mathrm{ha})\end{array}$ & $\begin{array}{c}\text { Biomass yield } \\
(\mathrm{kg} / \mathrm{ha})\end{array}$ \\
\hline \multicolumn{3}{|c|}{ Mean for variety } \\
\hline $\mathbf{V}_{1}$ & 4321 & 8063 \\
\hline $\mathbf{V}_{2}$ & 4537 & 8460 \\
\hline S.Em. \pm & 130.5 & 386.6 \\
\hline CD at $5 \%$ & NS & NS \\
\hline CV\% & 10.2 & 16.2 \\
\hline \multicolumn{3}{|c|}{ Mean for date of sowing } \\
\hline $\mathbf{D}_{1}$ & 5396 & 12997 \\
\hline $\mathbf{D}_{2}$ & 4682 & 8123 \\
\hline $\mathbf{D}_{3}$ & 3209 & 3666 \\
\hline S.Em. \pm & 150.4 & 415.8 \\
\hline CD at $5 \%$ & 463.5 & 1281.5 \\
\hline V $\times D$ & 212.7 & 588.1 \\
\hline CV\% & 9.6 & 14.2 \\
\hline
\end{tabular}




\section{No. of bolls/plant}

Data regarding no. of bolls/plant of Bt-cotton recorded at harvest as influenced by variety and dates of sowing are presented in Table 2 .

The higher no. of bolls/plant was observed in cultivar RCH-2 (33 bolls/plant) followed by Vikram-5 (29 bolls/plant) the time at harvest. The early sown Bt-cotton $\mathrm{D}_{1}$ recorded highest (36 bolls/plant) bolls/plant followed by $\mathrm{D}_{2}(29$ bolls/plant) dates and $\mathrm{D}_{3}$ (28 bolls/plant). The results were in accordance to Arshad et al., (2011) for Bt-cotton yield.

\section{Seed cotton and dry biomass yield (kg/ha)}

\section{Effect of varieties}

It may be seen from the Table 3, that the differences in seed cotton yield of Bt-cotton due to varieties were non-significant. Higher seed cotton yield $(4536 \mathrm{~kg} / \mathrm{ha})$ was obtained with variety $\mathrm{V}_{2}$ as compared with variety $\mathrm{V}_{1}$ (4312.2 kg/ha).

The biomass yield of cotton was also found non-significant, however, higher biomass yield was recorded in $\mathrm{V}_{2}$ cultivar $(8460 \mathrm{~kg} / \mathrm{ha})$ as compared to $\mathrm{V}_{1}$ cultivar $(8063 \mathrm{~kg} / \mathrm{ha})$. The results were in accordance to Awan et al., (2011) for Bt-cotton yield.

\section{Effect of date of sowing}

The seed cotton and biomass yields of Btcotton as influenced by different sowing dates are presented in Table 3 . Significantly highest seed cotton yield $(5396 \mathrm{~kg} / \mathrm{ha})$ was obtained in early sown cotton (25th May $\mathrm{D}_{1}$ ) as compared to crop sown on 10th June $\left(\mathrm{D}_{2}\right)$ and 25th June $\left(\mathrm{D}_{3}\right)$.

With delay in sowing the seed cotton yield reduced by $15 \%$ and $68 \%$ in $\mathrm{D}_{2}$ and $\mathrm{D}_{3}$ respectively over $\mathrm{D}_{1}$ sown crop. The highest biomass yield $(12996.79 \mathrm{~kg} / \mathrm{ha}$ ) was recorded with the crop sown on 25th May $\left(D_{1}\right)$, whereas later sown crop gave significantly lower yield $(8123 \mathrm{~kg} / \mathrm{ha})$ 10th June $\left(\mathrm{D}_{2}\right)$ and $(3666 \mathrm{~kg} / \mathrm{ha})$ on 25 th June $\left(\mathrm{D}_{3}\right)$.

It might be due to early maturity achieved in third date of sowing. This is in agreement with the comparatively small accumulation of heat units in third date of sowing (2936 0C days). The results were in accordance to Arshad et al., (2007) for Bt-cotton yield.

\section{Interaction effect of $\mathrm{V} \times \mathrm{D}$}

The interaction effect among the different varieties and date of sowing showed significantly variation in all the parameters presented in Table 3.

In general, looking to all the yield attributing characters interaction effect inferences, it was concluded that cultivar Vikram-5 was found most suitable cultivar for sowing at early sowing for optimum seed cotton and biomass yield.

In conclusion the results of present experiment show that the total crop duration varied with the dates of sowing. The crop life period was found to be shortened with delay in sowing, more pronounced being in cv. Vikram-5. The total yield and yield attributes of cotton as influenced by different treatments showed that the first date of sowing $\left(D_{1}-25\right.$ th May) had produced significantly higher seed cotton yield as well as yield attributes than other dates mentioned.

\section{References}

Akhtar, M., Chima, M. S., Moazzam Jamil, Shahid Shaukat Ali and Shahid I., (2002). Response of cotton genotypes to time of sowing. Asian Journal of 
Plant Sciences., 1 (5): 538-539.

Anonymous, (2013). Genetically modified plants: Global Cultivation Area. http://www.gmo-compass.org.

Anonymous, (2017-18), ICAR-All India Coordinated Research Project on Cotton - Annual Report (2017-18). http://aiccip.cicr.org.in.

Ansari, M. D. Shahim and Mahey, R.K., (2003). Growth and yield of cotton species as affected by sowing dates and nitrogen levels. Journal of Research Punjab Agriculture University, 40 (1): 8-11.

Anuradha, N. and Reddy, A. R. (2011). Analysis of Growth and Instability of cotton production in India, "World Cotton Research Conforance". 7-11 November, 2011. Mumbai. pp.450-453.

Arshad, M., maqsood, M., Wajid, A., Hussain, K., Aslam, M. and Ibrahim, M. (2007). Response of growth, yield and quality of different cotton cultivars to sowing dates. Pak. J. Agric., 44 (2). 118-122.

Awan, H., Awan, I., Mansoor, M., Khan, E.A., and Khan, M., (2011). Effect sowing time and plant spacing on fiber quality and seed cotton yield. Sarhad J. Agric. 27 (3): 411-413.

Bozbek, T., Sezener, V., and Unay, A. (2006). The effect of sowing date and plant density on cotton yield. Journal of Agronomy, 5(1): 122-125.

Brar, A. S. and Singh, T. H., (1994). Reappraisal of the optimum sowing period for American cotton in Punjab: Effect on yield and yield components. Journal of Indian Society for Cotton Improvement, 19 (2): 157-160.

Brar, A. S., Rajinder Singh, and Singh, T. H., (1990). A note on the performance of Hirsutum cotton varieties under different sowing dates and spacing. Indian Society for Cotton Improvement
Journal, 15 (1): 47-48.

Brar, A. S., thind, R. J. S., Kular, J. S. and Singh, T. H., (1996). Effect of sowing time, spacing and nitrogen levels on upland cotton cultivars in Punjab. Journal of Indian Society for cotton improvement, 21 (1): 41-44.

Buttar, G. S., Mahay, R. K. and Aggarwal, N., (2005). Effect of sowing dates, planting methods and irrigation scheduling on the growth and yield of American Cotton. Journal of Cotton Research and Development, 19 (2): 213-215.

Dhoble, M. V., Giri, D. G., Patil, V. D. And Pawar, B. R., (1988). Productivity of cotton varieties as influenced by sowing dates and plant densities. Journal of Maharastra Agricultural Universities, 13(2): 177-179.

Hanuman Prasad, Nehra, P. L., Gothwal, D. K. And Harphool Singh, (2000), Effect of date of sowing and spacing on seed cotton yield. Journal of Cotton Research and Development, 14 (2): 232-234.

Koraddi, V. R., Basavanna, P., Guggari, A. K., and Kamath, K. S., (1992). Response of rainfed cotton to sowing dates, spacing and fertilizer levels. Journal of Maharastra Agriculture Universities, 17 (1): 69-72.

Nehra, P. L. and Matish Chandra, (2001). Performance of Hirsutum cotton under different sowing dates and spacing. Journal of Cotton Research and Development, 15 (2): 147-150.

Singh, I. and Nagda, B. L. (1996). Effect of sowing date, spacing and nitrogen level on upland cotton. Indian Journal of Agricultural Sciences. 66(5): 293-4.

Srinivasan, G., (2001). Response of summer irrigated cotton (Gossypium hirsutum) to sowing dates and nutrient management practices. Indian Journal of Agronomy, 46 (3): 552-556. 


\section{How to cite this article:}

Vibha Tak, Vyas Pandey and Parmar, P. K. 2021. Effect of Date of Sowing and Varieties on Yield of Kharif Bt-cotton in Middle Gujarat Agro-Climatic Region. Int.J.Curr.Microbiol.App.Sci. 10(01): 2217-2222. doi: https://doi.org/10.20546/ijcmas.2021.1001.254 